\title{
Erwinia carotovora pv. carotovora, causal agent of soft rot disease in some crops in Puerto Rico'
}

\author{
Amelia Cortés-Monllor
}

\begin{abstract}
The bacterium Erwinia carotovora pv. carotovora (Jones) was identified from bacterial isolates from decaying material of tobacco, fomato, tanier, head lettuce, cabbage, Dracaena spp, Pothos spp, and calla lily as the causal agent of soft rot disease. Physiological characteristics, biochemical reactions and antibiotic response were similar among strains. The abilify of the isolates to produce soft rot symptoms on healthy plants when artificially inoculated was demonstrated by pathogenicity tests.

\section{RESUMEN}

Erwinia carotovora pv. carotovora, agente causante de la podredumbre blanda en algunas cosechas en Puerto Rico

Erwinia carotovora pv. carotovora es el causante de la podredumbre de cultivares en Puerto Rico. Se estudió el organismo causante de la podredumbre blanda aislado en tabaco, tomate, yautía, lechuga repollada, repollo y las ornamentales Pothos sp., Dracaena sp. y lirio cala. Las características fisiológicas, reacciones bioquímicas y sensitividad a antibióticos fueron similares entre los distintos aislamientos obtenidos. Pruebas de patogenicidad demostraron sintomas de podredumbre blanda en las distintas hospederas inoculadas. El organismo se identificá como $E$. carotovora pv. carotovora (Jones).
\end{abstract}

\section{INTRODUCTION}

Erwinia carotovora, described by Jones (11) as Bacillus carotovora, was known to produce soft rot disease in carrots as early as 1901 when he studied and described it. In 1904 a bacterial pathogen producing soft rot in tomato was named Bacillus aroideae by Townsend (13). Numerous synonyms $(1,12)$ have since been accepted for this organism which causes soft rot in various plants and vegetables (9).

In Puerto Rico, in 1935, Cook (2) reported a soft rot of tanier caused by $E$. carotovora (Jones). No records of the identification studies exist. Throughout the years, soft rot of local crops and ornamentals has been extensively observed. Plantings of tobacco, tomato, tanier, head lettuce, and cabbage are among the cultivars infected throughout different areas in Puerto Rico (table 1). Commercial nurseries of ornamentals such as Dracaena spp, Pothos spp, and calla lily have evidence of the same dis-

'Manuscript submitted to Editorial Board 17 August 1988.

${ }^{z}$ Associate Bacteriologist, Department of Crop Protection. 
TABLE 1.-Plant diseases caused by E. carotovora pv. carotovora in some localities in Puerto Rico

\begin{tabular}{|c|c|c|}
\hline Plant disease & Source of isolation & Oceurence \\
\hline \multirow[t]{2}{*}{ 1. Hollow stem } & $\begin{array}{l}\text { Nicotiana tabacum L. } \\
\text { (tobacco) }\end{array}$ & San Lorenzo \\
\hline & $\begin{array}{l}\text { Lycopersicon Lycopersicum L. } \\
\text { (tomato) var. Ace } 500 \\
\text { Floradel } \\
\text { Walter }\end{array}$ & $\begin{array}{l}\text { Guayama } \\
\text { Guayama } \\
\text { Rio Grande }\end{array}$ \\
\hline \multirow[t]{2}{*}{ 2. Soft rot of rhizome } & $\begin{array}{l}\text { Zantedeschia aethiopica (Spreng) } \\
\quad \text { (Calla lily) }\end{array}$ & Aibonito \\
\hline & $\begin{array}{l}\text { Xanthosoma sagittifolizm (L.) Schott } \\
\text { (Tanier) }\end{array}$ & $\begin{array}{l}\text { Rio Piedras } \\
\text { Corozal } \\
\text { Orocovis } \\
\text { Villalba }\end{array}$ \\
\hline \multirow[t]{4}{*}{ 3. Soft rot of stem } & $\begin{array}{l}\text { Lactuca sativa L. } \\
\quad \text { (lettuce) }\end{array}$ & Juana Diaz \\
\hline & $\begin{array}{l}\text { Brassica oleracea var. capilata } \mathrm{L} . \\
\text { (cabbage) }\end{array}$ & Juana Díaz \\
\hline & $\begin{array}{l}\text { Epiprenum aureum (Lindé \& André) Bunt. } \\
\quad \text { (Pothos) }\end{array}$ & Dorado \\
\hline & Dracaenasp. & Río Piedras \\
\hline
\end{tabular}

ease. Rot is a symptom response of a plant to invasion by bacteria or fungi. Bacterial soft rot organisms are destructive in the field whether they invade a whole plant or part of it. Having invaded before harvest, the organism multiplies while in storage or transit (under favorable temperature conditions) thus affecting marketability.

The disease caused by this bacteria is characterized by moist or watery tissue of a brownish color. Gradually, the tissue becomes soft and slimy giving off a putrid offensive odor which is due to the destroyed cells and the disintegration of the pectin by the enzyme pectinase produced by the organism.

In this paper I describe the results of the studies of physiological characters and biochemical activites performed to identify and classify the organism.

\section{MATERIAL AND METHODS}

\section{Source and symptoms}

Tobacco-Mature plants in the field presented a withered appearance. Longitudinal sections of the stem revealed a dark brown discoloration with a decomposing mass in the vascular pith that gradually became hollow. Younger plants exhibited only a slimy soft rot. 
Head lettuce and cabbage-Plants presented a severe rot infection characterized by a slimy decay, brown discoloration, eventually becoming a wet mass of rotten tissue. Split stem showed longitudinal brownish streaks, early rot and foul smell.

Tomato-Cultivars of Floradel, Ace 500, and Walter presented stem cracks, moderate wilt and hollow stem. Few plants appeared bent down.

Tanier-Rhizomes presented soft areas with decomposing tissue and strong putrid odor.

Calla lily-Young plants were slightly chlorotic, stunted and presented a soft area in the bulb or rhizome.

Dracaena spp.-The stem of young plants presented a soft area with broken tissue a few inches above the top soil.

Pothos spp.-The whole plant presented a rotting appearance, wilted leaves and collapsing stem and roots.

\section{Cultural studies}

Isolations were performed using diseased material collected from each of the crops mentioned in the preceding section. Whenever possible, samples were washed under water faucet to rinse away dirt and surface contamination. Pieces from the area between infected and healthy tissue were cut, immersed in a $5.25 \%$ solution of sodium hypochlorite for 1 to 2 $\mathrm{min}$, and washed in sterile distilled water. The tissue was teased apart in 1-2 ml tryptone glucose broth (TGB) and allowed to stand for $1 \mathrm{~h}$ at $28^{\circ} \mathrm{C}$. Plates of tryptone glucose agar (TGA) were smeared with a loopful of the suspension and incubated at $28^{\circ} \mathrm{C}$. Individual colonies visible after $24 \mathrm{~h}$ were restreaked into McConkey (Mc) agar $(6,7)$ plates and Logan's $(4,10)$ differential medium for Erwinias. Standard media and methods used in the identification of the causal agent were followed as previously described by Cortés-Monllor and Ruiz (3).

\section{Pathogenicity test}

Distinct colony cultures were tested for ability to produce soft rot in potato and carrot slices. The test was performed by pricking through a drop of bacterial suspension $\left(10^{7}\right.$ cells $\left./ \mathrm{ml}\right)$ with a sterile needle. Inoculated tissue was placed in humid plastic chambers at room temperature and observed for the production of soft rot. Those soft rotting bacteria were inoculated onto healthy plants of tobacco, tomato and potato by the stem pricking method. Plants were kept in a chamber with controlled humidity $(86 \%)$ and temperature $\left(85^{\circ} \mathrm{C}\right)$.

\section{Sensitivity test}

The susceptibility disk system (5) was used to measure in vitro susceptibility of the organism to different antibiotics. Performance of the test was followed as stated in Difco (6). After $24 \mathrm{~h}$ incubation at $37^{\circ} \mathrm{C}$, the plates were observed for zones of inhibition of bacterial growth which 
would indicate the susceptibility of the organism to the antibiotic tested. Resistant organisms produce no zone of inhibition.

\section{RESULTS}

The organism is a gram negative bacillus devoid of capsule. In a motility test medium a diffuse zone of growth spreads from the line of inoculation.

Colonies visible on TGA $24 \mathrm{~h}$ after incubation were small, approximately $0.5-1 \mathrm{~mm}$ in diameter, grayish-white, glistening, slightly raised, wet and round with crenated edge. On Mc agar, in $24 \mathrm{~h}$, minute grayish colonies were observed. Gradually in 36 to 48 hours, the colonies developed a red dot center surrounded by a grayish border. Eventually, the colony became totally red with an opaque zone of precipitation. Mc agar is suitable for detecting members of the enterobacteria group because it inhibits gram positive bacteria. Furthermore, the lactosefermenting organisms, due to the action of the acids, precipitates the bile salts, and thus changes the color of the colonies to red $(6,7)$. Logan's medium (10) is based on the reduction of triphenyl tetrazolium chloride, an indicator useful for detecting fermentative organisms. The nonfermentant strains are stained deep red and the fermenters remain colorless. $E$. carotovora pv. carotovora colonies approximately $1-1.5 \mathrm{~mm}$ in diameter developed a pink to dark red center surrounded by a grayish border after $24 \mathrm{~h}$.

Among the biochemical characteristics which distinguished this group was the ability to produce acid without gas from lactose, glucose, salicin and trehalose but not from maltose, and the rapid liquefaction of gelatin and pectate degradation by action of proteolytic enzymes.

In litmus milk, as the organism acted upon lactose and glucose, the color changed to red (acid) and the lactic acid formed coagulated the caseinogen. It utilized citrate and esculin as a source of carbon but not malonate or starch, and tolerated $5 \%$ to $8 \%$ salt. It was able to reduce nitrates to nitrites but not to split fats and oils. From the break-out of peptone $\mathrm{H}_{2} \mathrm{~S}$ evolved turning the lead acetate paper strip black, but no ammonia nor indole was produced. The oxidase and catalase tests were negative. Tables $2,3 \mathrm{~A}$ and $\mathrm{B}$ show the results obtained from the different tests performed.

\section{Pathogenicity test}

Slices of potato and carrots inoculated in vitro presented a watery light cream exudate $24 \mathrm{~h}$ after infected. Gradually, in $48 \mathrm{~h}$, the macerated area on the potato slices developed a dark brown edge, extending beyond the point of inoculation. Healthy tomato, tobacco and potato plants inoculated with the various isolates (table 4) presented similar symptoms. Three days after inoculation, affected plants were slightly wilted; leaves became flaccid with brown watery veins; the stem was brownish and 


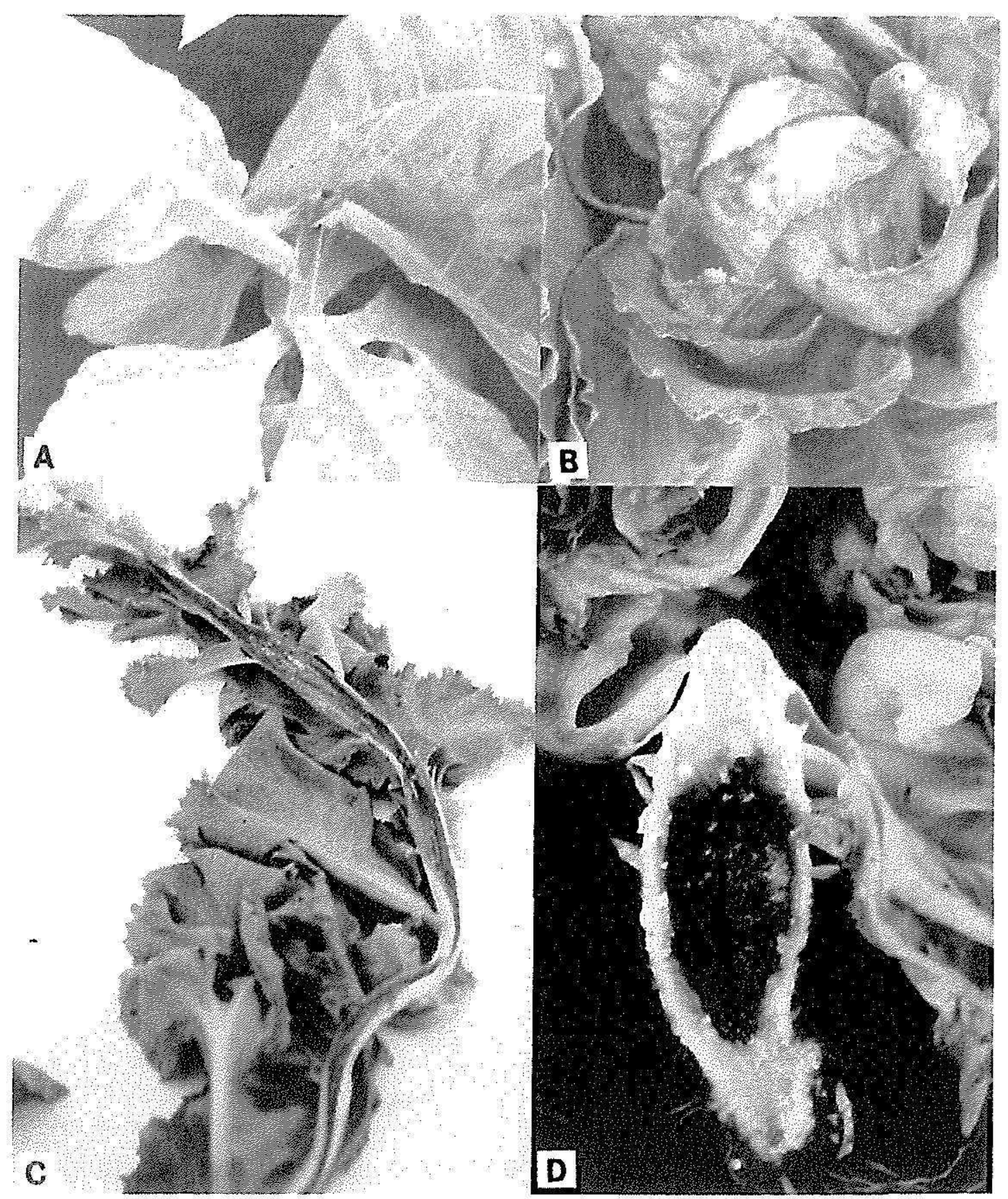

PLATE 1. Symptoms expressed by different crops after inoculating with a suspension of E.c. pv. carotovora isolated from diseased head lettuce.

A. Initial symptoms of hollow stem rot of tobacco.

B. Slimy decay, brown discoloration and soft rot of cabbage.

C. Brown soft rot, hollow stem of leaf lettuce.

D. Split open stem of head lettuce showing severe soft rot, black discoloration.

slimy at touch. Eventually, the top of a few plants dropped. Longitudinal sections of the stem, showing dark-brown discoloration of the vascular tissue, became hollow. Affected tomato plants also presented stem cracks 
TABLE 2.-Behavioner E. carotovora pv. carotovora

\begin{tabular}{ll}
\hline \multicolumn{1}{c}{ Test } & \multicolumn{1}{c}{ Response } \\
\hline $\begin{array}{l}\text { Gram stain and morphology } \\
\text { Colony appearance } \\
\text { TGA-24h }\end{array}$ & Negative, rod \\
& Small, grayish, glistening, crenated \\
MC Agar & edge and grow at $37^{\circ} \mathrm{C}$ \\
& Small, red center surrounded by \\
Logan's medium & grayish border. \\
& Small, dark red center surrounded \\
Motility medium & by grayish border. \\
Capsule stain & Diffuse zone of growth \\
Oxidase & Negative \\
Catalase & Negative \\
Maceration of potato slice & Negative \\
\hline
\end{tabular}

and a few necrotic spots on the leaves. Black soft rot was observed on infected potato plants, which finally collapsed. Plate 1 presents symptoms on various hosts inoculated.

\section{Sensitivity test}

The various strains were constantly sensitive to tetracycline, aureomycin, chloroamphenicol, streptomycin, neomycin and novobiocin. Variable responses were obtained to bacitracin and polymyxin $\mathrm{B}$, and insensitiveness or resistance to erythromycin, penicillin and nystatin. Results of the susceptibility test are stated in table 5 .

\section{DISCUSSION}

Diagnoses of Erwinia spp., based primarily on disease symptoms, colony and pigment characteristics and some specific biochemical reactions are criteria used to classify an organism into a genus. The soft rot bacteria isolates from local decaying cultivars proved to be an Erwinia spp. The different strains produced similar symptoms in the various cultivars inoculated, some severer than others. Some differences in their biochemical activities and in their responses to antibiotics were observed. Although no differentiation between strains can be sustained, variability within the pathovars has been reported $(1,4,8)$.

The genus Erwinia has been a controversial group because of its common and differential characters. Related strains of Erwinia were grouped as the "soft rot or carotovora group" within the Enterobacter family. This has led many scientists to support Waldee's suggestion (14) to restrict those pathogens which attack the middle lamella causing soft rots due to the presence of pectolytic enzymes in a new genus Pectobacterium. To date, there exists general confusion, and no final agreement has been reached. Lelliott, in Bergey's edition (12), states a compromise 
TABIE 3.-reactions of E. carotovora pv. carotovora isolaled from various sources

A. Biochemical Test

\begin{tabular}{|c|c|c|c|c|c|c|c|c|}
\hline \multicolumn{9}{|c|}{ SOURCE } \\
\hline TEST & Cabbage & $\begin{array}{l}\text { Calla } \\
\text { lily }\end{array}$ & $\begin{array}{c}\text { Dracaena } \\
\text { sp. }\end{array}$ & Lettuce & $\begin{array}{l}\text { Pothos } \\
\text { sp. }\end{array}$ & Tanier & Tobacco & Tomato \\
\hline Indole & - & - & - & - & - & - & - & - \\
\hline $\mathrm{NH}_{3}$ & - & - & - & - & - & - & - & - \\
\hline MR-VP &,-+1 &,-- &,-+ &,++ &,+- &,+- &,+- &,-+ \\
\hline $\mathrm{NO}_{3}$ & + & + & + & + & + & + & + & + \\
\hline Milk & & & & & & & & \\
\hline (Litmus) & $\mathrm{AC}^{2}$ & $\mathrm{AC}$ & $\mathrm{AC}$ & $\mathrm{AC}$ & $A C$ & $\mathrm{AC}$ & $\mathrm{AC}$ & $\mathrm{AC}$ \\
\hline Citrate & + & + & + & + & + & + & + & + \\
\hline Malonate & - & + & - & - & - & - & - & - \\
\hline Urea & - & - & - & - & - & - & - & - \\
\hline $\mathrm{H}_{22} \mathrm{~S}$ & & & & & & & & \\
\hline (Peptone) & $\div$ & + & + & + & + & + & + & + \\
\hline Gelatin & + & + & + & + & + & + & + & + \\
\hline Pectate & + & + & + & + & + & + & + & + \\
\hline Esculin & $\therefore$ & + & . & + & . & + & + & + \\
\hline Lypolisis & - & - & - & - & . & - & - & - \\
\hline Starch & - & - & - & - & . & - & - & - \\
\hline Salt & & & & & & & & \\
\hline Tolerance & $5 \%$ & . & $7 \%$ & . & $5 \%$ & $5 \%$ & $8 \%$ & $7 \%$ \\
\hline \multicolumn{9}{|c|}{ B. Acid production on carbohydrates } \\
\hline Sucrose & + & + & + & + & + & + & + & + \\
\hline Lactose & + & + & + & + & + & + & $\div$ & + \\
\hline Glucose & + & + & + & + & + & + & + & + \\
\hline Maltose & - & - & - & - & - & - & - & - \\
\hline Salicin & + & + & + & + & + & + & + & + \\
\hline Glycerol & + & - & + & . & + & + & + & . \\
\hline Dextrine & + & . & - & - & - & - & - & - \\
\hline Dulcitol & + & . & - & - & - & - & - & - \\
\hline Sorbitol & - & - & - & - & - & - & - & - \\
\hline Trehalose & . & + & . & + & . & + & + & + \\
\hline
\end{tabular}

retaining the genus Erwinia divided in 3 groups (amylovora, herbicola and carotovora). The nonfermenter soft rot bacterium $E$. carotovora var. aroideae (Townsend) has been placed under the carotovora group, $E$. carotovora var. carotovora. Since none of the local strains were able to produce gas from carbon, we will identify this pathogen Envinia carotovora pv. carotovora as the causal agent of bacterial soft rot disease in tomato, tobacco, head lettuce and cabbage, and ornamentals calla lily, 
TABLE 4.-Symptoms expressed by various hosts after inoculation with soft-rot isolates of Erwinia spp

\begin{tabular}{|c|c|c|c|c|c|c|c|}
\hline \multirow{2}{*}{$\begin{array}{l}\text { Hosts } \\
\text { tested }\end{array}$} & \multicolumn{7}{|c|}{ Source of Erwinia spp. isolates } \\
\hline & Dracaena sp. & Pothos sp. & Cabbage & Lettuce & Tanier & Tobacco & Tomato \\
\hline Tomato & $\begin{array}{l}\text { Wilt } \\
\text { Rot } \\
\text { Hollow stem }\end{array}$ & $\begin{array}{l}\text { Rot } \\
\text { Hollow stem }\end{array}$ & * & $\begin{array}{l}\text { Brown } \\
\text { Soft-rot } \\
\text { Hollow stem }\end{array}$ & $\begin{array}{l}\text { Wilt } \\
\text { Rot } \\
\text { Hollow stem } \\
\text { Death }\end{array}$ & $*$ & $\begin{array}{l}\text { Stem crack } \\
\text { Stem rot } \\
\text { Necrotic spots } \\
\quad \text { on leaves }\end{array}$ \\
\hline Tobacco & Soft-rot stem & $\begin{array}{l}\text { Rot } \\
\text { Hollow stem }\end{array}$ & $*$ & $\begin{array}{l}\text { Soft-rot } \\
\text { Hollow stem } \\
\text { Strong putrid } \\
\text { odor }\end{array}$ & $*$ & $\begin{array}{l}\text { Rot } \\
\text { Hollow stem }\end{array}$ & $\begin{array}{l}\text { Stem crack } \\
\text { Hollow stem }\end{array}$ \\
\hline Potato & $*$ & $\%$ & $\begin{array}{l}\text { Stem rot } \\
\quad \text { (Black) } \\
\text { Hollow stem } \\
\text { Death }\end{array}$ & $*$ & $\begin{array}{l}\text { Soft-rot } \\
\text { (Black) } \\
\text { Death }\end{array}$ & * & $\nLeftarrow$ \\
\hline
\end{tabular}

*No record 
TABLE 5.-Susceptibility test of E. carotovora po. carotovora, isolates from various sources, to different antibiotics

\begin{tabular}{|c|c|c|c|c|c|c|c|c|c|c|}
\hline \multirow[b]{2}{*}{ Antibiotic } & & \multirow[b]{2}{*}{$\begin{array}{l}\text { Concentration } \\
\text { per disk }\end{array}$} & \multicolumn{8}{|c|}{ Source } \\
\hline & & & Tobacco & Tomato & Cabbage & Lettuce & Tanier & $\begin{array}{l}\text { Calla } \\
\text { lily }\end{array}$ & Dracaena & Pothos \\
\hline Tetracycline & $\left(\mathrm{TE}_{30}\right)$ & $30 \mathrm{ug}$ & $S^{\prime}$ & S & S & S & $\mathrm{S}$ & S & S & S \\
\hline Aureomycin & $\left(A_{30}\right)$ & $30 \mathrm{ug}$ & $\mathrm{S}$ & S & S & S & S & S & $\mathrm{S}$ & $S$ \\
\hline Chloroamphenicol & $\left(\mathrm{C}_{30}\right)$ & $30 \mathrm{ug}$ & S & . & S & $S$ & S & $S$ & . & . \\
\hline Streptomycin & $\left(S_{10}\right)$ & 10 ug & $S$ & $S$ & $\mathrm{~S}$ & $\mathrm{~S}$ & S & $S$ & S & $S$ \\
\hline Polymyxin B & $\left(\mathrm{PB}_{300}\right)$ & 300 units & $\mathrm{R}$ & . & $\mathrm{S}$ & $\mathrm{S}$ & $\mathrm{S}$ & S & $S$ & s \\
\hline Neomycin & $\left(\mathrm{N}_{30}\right)$ & $30 \mathrm{ug}$ & $\mathrm{S}$ & . & S & $S$ & S & $\mathrm{S}$ & S & S \\
\hline Erythromycin & $\left(E_{15}\right)$ & $15 \mathrm{ug}$ & $\mathrm{R}$ & $\mathrm{R}$ & $R$ & $\mathrm{R}$ & $\mathrm{R}$ & $R$ & $\mathrm{R}$ & $\mathrm{R}$ \\
\hline Bacitracin & $\left(B_{10}\right)$ & 10 units & $S$ & . & $R$ & $\mathrm{R}$ & $S$ & $S$ & $R$ & $R$ \\
\hline Novobiocin & $\left(\mathrm{NB}_{30}\right)$ & 30 ug & $S$ & . & S & $S$ & $S$ & $S$ & . & . \\
\hline Nystatin & $\left(N Y_{100}\right)$ & 100 units & $\mathrm{R}$ & . & $\mathrm{R}$ & $\mathrm{R}$ & $R$ & $\mathrm{R}$ & . & . \\
\hline Penicillin & $\left(\mathrm{P}_{10}\right)$ & 10 units & $\mathrm{R}$ & $\mathrm{R}$ & $\mathrm{R}$ & $\mathrm{R}$ & $\mathrm{R}$ & $\mathrm{R}$ & $\mathrm{R}$ & $\mathrm{R}$ \\
\hline
\end{tabular}

IS = Susceptible or zone of inhibition around disk. $R=$ Resistant or no zone of inhibition around disk. . = Test not performed. 
Dracaena and Pothos spp. in Puerto Rico. At the same time, identification studies for the bacterial soft rot disease in taniers, previously reported by Cook (2) in Puerto Rico, are presented.

\section{LITERATURE CITED}

1. Bradbury, J. F., 1977. Envinia carotovora pv. carotovora, Commonwealth Mycological Institute (CMI) Descriptions of Pathogenic Fungi and Bacteria No. 552, Kew, Surrey, England.

2. Cook, M. T., 1937. Ann. Rep. Univ. P. R., Agric. Exp. Stn., 1985-36, p. 135.

3. Cortés-Monllor, A. and H. Ruiz, 1987. Bacterial leaf spot of pigeon pea in Puerto Rico. J. Agric. Unive. P. R. 71 (2): 177-84.

4. Cother, E. J. and K. Sivasithamparam, 1983. Erwinia: The "Carotovora" group. In: Plant Bacterial Diseases: a diagnostic guide. P. C. Fahy and G. J. Persley (Ed). Academic Press, Australia, 393 pp.

5. Difco Laboratories, 1988. Quality Products for Microbiology, P. O. Box 1058, Detroit, MI. 48232.

6. Difco Manual of Dehydrated Culture Media and Reagents for Microbiological and Clinical Laboratory Procedures, 1977, Ninth Ed., Detroit 1, MI.

7. Dowson, W. J., 1957. Plant Diseases Due to Bacteria, 2nd ed., Cambridge University Press, Cambridge, England.

8. Dye, D. W., 1983. Erwinia: The "Amylovora" and "Herbicola" Groups. In: Plant Bacterial Diseases: a diagnostic guide. P. C. Fahy and G. J. Persley (Ed). Academic Press, Australia, $393 \mathrm{pp}$.

9. Elliott, C., 1951. Manual of Bacterial Plant Pathogens, 2nd ed., Chronica Botanica Company, Waltham, MA.

10. Fahy, P. C. and A. C. Hayward, 1983. Media and Methods for Isolation and Diagnostic Test. In: Plant Bacterial Diseases: a diagnostic guide. P. C. Fahy and G. J. Persley (Ed). Academic Press, Australia, 393 pp.

11. Jones, L. R., 1893. A bacterial sten rot of lettuce, Vermont Agric. Exp. Stn. 6th Ann. Rep., 1892, pp. 82-7.

12. Lelliott, R. A., 1974. Genus Erwinia. In: Bergey's Manual of Determinative Bacteriology, 8th ed., The Williams and Wilkins Co., Baltimore, MD.

13. Massey, A. B., 1924. A study of Bacillus aroideae Townsend, the cause of a soft rot of tomato, and B. carotovomis Jones, Phytopath. 14: 460-77.

14. Waldee, E. L., 1945, in Dowson, W. J., 1957. Plant diseases due to Bacteria, 2nd ed., Cambridge University Press, Cambridge, England. 